\title{
HUBUNGAN SELF-COFIDENCE DENGAN KEMAMPUAN KOMUNIKASI MATEMATIK SISWA SMP
}

\author{
Siti Muniroh ${ }^{1}$, Tina Rosyana ${ }^{2}$, Heris Hendriana ${ }^{3}$ \\ 1,2,3 Institut Keguruan dan Ilmu Pendidikan (IKIP) Siliwangi Bandung, Indonesia \\ ${ }^{1}$ sitimuniroh432@gmail.com, ${ }^{2}$ tinarosyana@gmail.com, ${ }^{3}$ herishen@yahoo.com
}

\begin{abstract}
This study examines the relationship between self-confidence with students' mathematical communication skills. This research uses expost pacto method with correlation analysis technique. The population in this study is all students of class IX in one of the SMP Negri in Cimahi city (IX.A - IX.N) with the number of 504 students / The academic year 2017/2018. As for the sample in this study is the students of SMP class IX N with the number of 36 students / i. In this study using cluster random sampling technique that is random sampling. In the data collection is by using the questionnaire instrument (self-confidence questionnaire) and test of mathematical communication skills. Further data is analyzed quantitatively by using Pearson correlation formula in SPSS application. The results showed that there was a positive relationship between self-confidence with students' mathematical communication ability, with correlation coefficient value of 0.865 and Sig. (2-tailed) 0.000 .
\end{abstract}

Keywords: Self-Confidence, Communication Skill

\begin{abstract}
Abstrak
Penelitian ini menelaah tentang hubungan antara Self- Confidence (kepercayaan diri) dengan kemampuan komunikasi matematik siswa, dalam penelitian ini menggunakan metode expost pacto dengan teknik analisis korelasi. Adapun populasi dalam penelitian ini yaitu seluruh siswa kelas IX di salah satu SMP Negri di kota Cimahi (IX.A - IX.N) dengan jumlah 504 siswa/i Tahun ajaran 2017/2018. Sedangkan sampel dalam penelitian ini adalah siswa SMP kelas IX N dengan jumlah 36 siswa/i. Dalam penelitian ini pengambilan sample dilakukan secara acak. Pengumpulan datanya yaitu dengan menggunakan instrumen kuesioner (angket Self-Confidence / kepercayaan diri) dan soal tes kemampuan komunikasi matematik. Selanjutnya data di analisis secara kuantitatif dengan menggunakan rumus korelasi pearson pada aplikasi SPSS. Hasil penelitian menujukan bahwa ada hubungan yang searah atau positif antara Self-Confidence (kepercayaan diri) dengan kemampuan komunikasi matematik siswa, dengan nilai koefien korelasinya yaitu 0,865 dan Sig.(2-tailed) nya 0,000.
\end{abstract}

Kata Kunci: Self-Confidence (kepercayaan diri), Kemampuan Komunikasi

How to cite: Muniroh, S., Rosyana, T., \& Hendriana, H. (2018). Hubungan Self-Cofidence dengan Kemampuan Komunikasi Matematik Siswa SMP. JPMI - Jurnal Pembelajaran Matematika Inovatif, 1 (4), 479-486.

\section{PENDAHULUAN}

Matematika adalah ilmu yang sangat penting dalam mendasari berbagai ilmu dan perkembangan teknologi modern serta dapat mengembangkan daya pikir manusia. Selain itu, matematika juga mempunyai fungsi sebagai bahasa simbolik yang memungkinkan terwujudnya komunikasi baik."Komunikasi adalah bagian yang penting dalam pelajaran matematika dan pendidikan matematika", Turmudi (Sritresna, 2017). Menurut Anshari (Elida, 2012) "kemampuan komunikasi matematik adalah suatu kemampuan dalam menjelaskan suatu 
proses pengerjaan dan cara unik atau berbeda dalam penyelesaian suatu masalah, kemampuan siswa dalam membangun dan menjelaskan sajian kejadian dunia nyata baik secara persamaan tabel, grafik, kata-kata atau kalimat, dan sajian secara fisik".

Adapun indikator kemampuan komunikasi menurut Sumarmo (Afrilianto \& Rosyana, 2016) yaitu: "a) menghubungkan benda nyata, gambar dan diagram ke dalam gagasan matematika; b) menjelaskan gagasan, situasi dan relasi matematika, secara lisan dan tulisan, dengan benda nyata, gambar, grafik, dan aljabar; c) menyatakan peristiwa sehari-hari dalam bahasa atau simbol matematika; d) mendengarkan, berdiskusi dan menulis tentang matematika; e) membaca dengan pemahaman suatu presentasi matematik; f) Menyusun konjektur, menyusun argumen, merumuskan definisi dan generalisasi; g) mengungkapkan kembali suatu uraian atau paragraf matematika dengan bahasa sendiri”.

Mengingat pentingnya kemampuan komunikasi matematik didalam pembelajaran, menurut Enis (Hendriana, Rohaeti, \& Sumarmo, 2017) diantaranya adalah: “a) Ide matematika dapat digali melalui kemampuan komunikasi dalam berbagai persepektif; b) Dapat meningkatkan kemampuan melihat yang berkaitan dengan konten matematika untuk mempertajam cara berfikir; c) Untuk mengukur kemampuan pemahaman matematik; d) Dapat membangun cara berfikir siswa; d) Dapat membangun kemampuan pengetahuan matematika siswa; e) Dapat meningkatkan dalam kemampuan berfikir kritis, rasional, pemecahan masalah, dan keterampilan”.

Kemampuan komunikasi matematik siswa sangat penting diterapkan dalam diri seseorang karena kemampuan tersebut dapat menjadikan seseorang tumbuh dan berkembang dalam setiap pembelajaran (Rahmi, Nadia, Hasibah, \& Hidayat, 2017; Sumarmo, Mulyani, \& Hidayat, 2018; Zakiah, Saomi, Syara, Hidayat, \& Hendriana, 2018). Salah satunya pembelajaran di sekolah. Namun kenyataannya dilapangan, kegiatan pembelajaran di berbagai sekolah masih kurang dari hasilnya kurang dari hal diharapkan. Hal tersebut sesuai dengan hasil survey TIMSS dan PISA (Salam, 2014) bahwa "tingkat kemampuan komunikasi matematik siswa berada pada level yang rendah. Hal ini di sebabkan oleh beberapa faktor salah satunya Self-Confidence (kepercayaan diri)".

Menurut Lauster (Hendriana, 2013) mengatakan "bahwa Self-Confidence (kepercayaan diri) adalah sikap atau keyakinan atas kemampuan diri yang terdapat pada diri seseorang sehingga orang yang besangkutan tidak cemas dalam tindakan atau perbuatannya, merasa bebas melalukan segala hal yang diminatinya, dan bertanggung jawab". Self-Confidence (kepercayaan diri) juga dapat memberikan motivasi terhadap pencapaian suatu keberhasilan seseorang dalam menyelesaiakan permasalahannya. "Sehingga semakin tinggi self-confidence (kepercayaan diri) seseorang terhadap kemampuan diri yang dimiliki akan semakin kuat/tinggi pula seseorang dalam menyelesaikan pekerjaannya atau permasalahannya". Hendriana (Tresnawati, Hidayat, \& Rohaeti, 2017).

Adapun rendahnya Self-Confidence (kepercayaan diri) menurut Swallow (Rahayuningdyah, 2016) yaitu disebabkan oleh "kurangnya dalam berbicara atau berkomunikasi dengan orang lain, kurangnya ketertarikan dalam melakukan berbagai hal, menghindari lawan berbicara, dan memperlihatkan sikap pemarah kepada orang lain". Senada dengan pendapat Swallow, menurut Luritawa (Sritresna, 2017) berdasarkan hasil pengamatan di salah satu sekolah di kabupaten Garut, "siswa cenderung tidak percaya diri dalam bertanya, mengemukakan pendapat, dan menunjukan kemampuannya kepada orang lain, hal tersebut menujukan hampir $80 \%$ siswa mempunyai kepercayaan diri yang rendah". 
Menurut (Sidik, Ramlah, \& Utami, 2017) "jika seseorang mempunyai self-confidence (kepercayaan diri) yang baik atau tinggi, maka individu tersebut akan baik pula akan dan akan menjadikan keberhasilan dalam seseorang terutama dalam hal pembelajaran. Artinya jika selfconfidence (kepercayaan diri) siswa baik, maka ia akan menjadi sukses didalam proses pembelajaran yang dilakukan. Seorang siswa akan berhasil didalam proses pembelajaran disekolah jika siswa tersebut dapat mencapai tujuan pembelajaran." Berdasarkan penjelasan datas, maka rumusan masalah dalam penelitian ini adalah:

1. Apakah ada hubungan antara self-confidence (kepercayaan diri) dengan kemampuan komunikasi matematik siswa SMP?

2. Berapa persentase pencapaian siswa dalam menyelesaikan soal tes komunikasi matematik?

3. Seberapa tinggi self-confidence (kepercayaan diri) dalam mengikuti pelajaran matematika?

Selanjutnya dengan rumusan masalah diatas, tujuan penelitian ini adalah:

1. Untuk mengetahui apakah terdapat hubungan antara self-confidence (kepercayaan diri) dengan kemampuan komunikasi matematik siswa SMP

2. Untuk mengetahui berapa persentase pencapaian siswa dalam menyelesaikan soal tes komunikasi matematik

Untuk mengetahui seberapa tinggi self-confidence (kepercayaan diri) dalam mengikuti pelajaran matematika?

\section{METODE}

Metode yang digunakan dalam penelitian ini yaitu menggunakan expost pacto. Metode ini digunakan untuk mencari suatu kejadian, atau penyebab berubahnya secara keseluruhan pada variabel bebas yang telah terjadi, karena dengan metode ini, tidak semua masalah pendidikan dapat diteliti. Penelitian ini sama dengan penelitian eksperimen, tetapi pada penelitian ini tidak ada pengontrolan variabel, variabel bebas tidak dimanipulasi, dan tidak ada perlakuan.

Populasi dalam penelitian ini adalah seluruh siswa kelas IX (IX.A sampai dengan IX.N) di salah satu SMPN di kota Cimahi tahun ajaran 2017/2018 sebanyak 504 orang siswa. Alasan peneliti mengambil siswa kelas IX karena dapat dikatakan bahwa memiliki kemampuan tinggi di bandingkan dengan kelas tujuh dan delapan, sebab menurut guru matematika kelas IX mengatakan bahwa siswa kelas IX sudah terbiasa dengan soal-soal yang diberikan karena tiap pembelajaran siswa di beri latihan soal untuk di kerjakan, hal ini bertujuan untuk kelancaran dalam melaksanakan TO, US, maupun UN. Adapun pengambilan sampel dalam penelitian ini dilakukan secara acak yaitu dengan mengambil satu kelas dari tiga belas kelas yaitu kelas IX.N. Sampel dalam penelitian ini adalah 36 siswa kelas IX dari jumlah populasi 504 siswa.

Instrumen penelitian yang digunakan adalah instrumen tes dan instrumen non tes. Instrumen tes berupa soal tes kemampuan komunikasi matematik yang digunakan untuk melihat sejauh mana kemampuan siswa dalam menyelesaikan soal matematika, soal tersebut yang terdiri dari 
7 soal uraian dan instrumen non tes berupa angket self-confidence (kepercayaan diri) yang digunakan untuk menelihat kepribadian atau prilaku siswa dalam pembelajaran matematika, dengan menggunakan skala likert yang terdiri dari empat pilihan jawaban, yaitu sangat setuju (SS), setuju (S), tidak setuju (TS) dan sangat tidak setuju (STS) yang terdiri dari 20 pernyataan. Sebelum di gunakan penelitian, baik instrumen tes maupun instrumen non tes bahwa soal tersebut diambil dari hasil uji coba instrumen yang telah dihitung baik validitas, reliabilitas, daya pembeda dan tingkat kesukaran. Kemudian setelah didapat data hasil tes dan data hasil angket dilakukan uji analisis korelasi yang digunakan untuk mengetahui ada atau tidaknya hubungan antara self-confidence (kepercayaan diri) dengan kemampuan komunikasi matematik siswa.

\section{HASIL DAN PEMBAHASAN}

\section{Hasil}

Sesuai dengan rumusan masalah, maka hasil penelitian ini, memaparkan tentang apakah ada hubungan anatara self-confidence (kepercayaan diri) terhadap kemampuan komunikasi matematik siswa. Untuk menjawab permasalahan tersebut, yaitu dengan menggunakan program aplikasi SPSS yaitu dengan analis uji korelasi self-confidence (kepercayaan diri) dengan kemampuan komunikasi matematik.

Uji ini untuk melihat kekuatan yang searah antara dua variabel yang terus menerus saling berhubungan dengan data bersekala. Pengujian hipotesis berdasarkan skor akhir kemampuan komunikasi dan self-confidence (kepercayaan diri).

Berikut adalah presentase hasil analisis self-confidence (kepercayaan diri) siswa yang dapat dilihat dari hasil belajar matematika dengan jumlah sampel 36 orang siswa yang diberikan angket self-confidence (kepercayaan diri) yaitu 6 orang siswa yang menjawab sangat setuju atau $16,67 \%, 12$ siswa yang menjawab setuju atau 33,33\%, yang menjawab tidak setuju yaitu 16 atau $44,44 \%$ dan siswa yang menjawab sangat tidak setuju 2 orang atau 5,56\%. Hasil tersebut menunjukan bahwa sebagian besar indeks self-confidence (kepercayaan diri) siswa/i di salah satu SMP Negeri di kota Cimahi dikatakan kurang. Hal tersebut dapat dilihat pada banyaknya jawaban siswa/i yang negatif yaitu $27,77 \%$ atau 10 orang dari pada yang positif yaitu $11,11 \%$ atau 4 orang.

Tabel 1. Presentase Hasil Analisis Self-Confidence (Kepercayaan Diri) dalam Belajar Matematika

\begin{tabular}{lcc}
\hline Jawaban & Prekuensi & Presentase \\
\hline SS & 6 & $16,67 \%$ \\
S & 12 & $33,33 \%$ \\
TS & 16 & $44,44 \%$ \\
STS & 2 & $5,56 \%$ \\
\hline Jumlah & 36 & $100 \%$ \\
\hline
\end{tabular}

Adapun nilai hasil dari tes dari kemampuan komunikasi matematik siswa yaitu tertinggi 15 dan nilai terendah 9 dari nilai maksimal 4. Nilai rata-rata yang diperoleh adalah 12,14 dengan simpangan baku 1,807. Berdasarkan data tersebut dapat dibuat tiga kategori kemampuan komunikasi matematik siswa, yaitu kategori tinggi, sedang, rendah. 
Tabel 2. Jumlah Frekuensi Kategori Kemampuan Komunikasi Matematis Siswa

\begin{tabular}{lllll}
\hline No & Kategori & & & Jumlah \\
\cline { 2 - 4 } & Tinggi & Sedang & Rendah & \\
\hline FR & 15 & 12 & 9 & 36 \\
NP & $41,67 \%$ & $33,33 \%$ & $25 \%$ & $100 \%$ \\
\hline
\end{tabular}

Keterangan:

FR : Frekuensi Responden

NP : Nilai Persentase

\section{Jumlah dan Presentase Kemampuan Konunikasi} Matematik Siswa SMP di Kota Cimahi

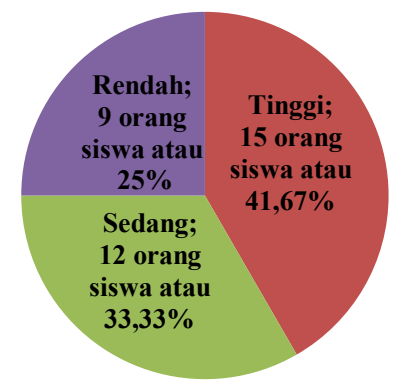

\section{Tingi}

Sedang

Rendah

Gambar 1. Diagram Jumlah Frekuensi Siswa Kemampuan Komunikasi Matematik

Berdasarkan Tabel 2 dan Gambar 1 tersebut menjelaskan bahwa sebagian besar kemamapuan komunikasi matematik siswa termasuk dalam kelompok sedang. Siswa dapat membaca soal dalam bentuk gambar, diagram, dan menghubungkannya kedalam ide matematika, siswa dapat menjelaskan ide, dan dapat menghubungkannya kedalam matematika melalui bentuk tulisan, gambar, diagram, dan melalui simbol atau bahasa matematika siswa dapat menyatakan idenya kedalam peristiwa sehari-hari. Walaupun siswa mampu menyelsaikan soal-soal terebut tetapi masih terdapat jawaban yang masih kurang lengkap dalam menjawab.

Selanjutnya dilakukan uji korelasi dengan taraf signifikansinya 0,05 dengan kriteria pengambilan keputusannya adalah :

i) Jika nilai sig $<0,05$ maka $\mathrm{H}_{0}$ diterima, artinya terdapat hubungan antara kemampuan komunikasi matematik dengan self-confidence (kepercayaan diri) siswa

ii) Jika nilai sig $\geq 0,05$ maka $\mathrm{H}_{\mathrm{o}}$ ditolak, artinya tidak terdapat hubungan antara kemampuan komunikasi matematik dengan self-confidence (kepercayaan diri) siswa

Berdasarkan hasil analisis korelasi, di dapat nilai sig (2-tailed) yaitu 0,000, sehingga $\mathrm{H}_{\mathrm{o}}$ diterima. Hal ini mempunyai arti bahwa ada hubungan yang signifikan antara Self-Confidence (kepercayaan diri) dengan kemampuan komunikasi matematik. Nilai koefisien korelasi menujukan besarnya koefisien anatara kemampuan komunikasi dan Self- Confidence (kepercayaan diri) yaitu 0,865. Menurut interpretasi koefisien korelasi, artinya bahwa ada hubungan yang searah atau positif antara Self- Confidence (kepercayaan diri) dengan kemampuan komunikasi matematik siswa. Seperti pada tabel dibawah ini: 
Tabel 3. Hasil Uji Korelasi

\begin{tabular}{|c|c|c|c|}
\hline & & kepercayaan diri & $\begin{array}{l}\text { Kemampuan } \\
\text { komunikasi }\end{array}$ \\
\hline \multirow[t]{3}{*}{ kepercayaan diri } & $\begin{array}{l}\text { Pearson } \\
\text { Correlation }\end{array}$ & 1 &, $865^{* *}$ \\
\hline & Sig. (2-tailed) & & ,000 \\
\hline & $\mathrm{N}$ & 36 & 36 \\
\hline \multirow[t]{3}{*}{ ikasi } & $\begin{array}{l}\text { nPearson } \\
\text { Correlation }\end{array}$ &, $865^{* *}$ & 1 \\
\hline & Sig. (2-tailed) &, 000 & \\
\hline & $\mathrm{N}$ & 36 & 36 \\
\hline
\end{tabular}

Tujuan diri yang positif berada pada dalam diri, pandangan, maupun perbuatan seesorang atau sikap yang menimbulkan rasa positif terhadap diri. Senada dengan Berzonsky (Rahmaningsih \& Martani, 2014) "konsep diri adalah sebuah personal theory yang mengenai seluruh konsep, yang dipercayainya oleh tujuan, dan harapan seseorang yang berhubungan dalam kehidupannya".

Hasil tersebut menunjukan bahwa ada hubungan yang searah (linear) antara Self-Confidence (kepercayaan diri) siswa dengan kemampuan komunikasi matematik siswa. Artinya, semakin tinggi self-confidence siswa maka akan mengakibatkan semakin tinggi pula kemampuan komunikasi matematiknya. Begitu juga sebaliknya semakin rendah self-confidence siswa maka akan mengakibatkan semakin rendah pula kemampuan komunikasi matematiknya.

Senada dengan penelitian (Sidik et al., 2017) "semakin besar atau tinggi (kepercayaan diri) seseorang maka kemampuan komunikasi matematik dalam dirinya akan semakin tinggi juga". Begitupun sebaliknya semakin rendah kemampuan komunikasi seesorang maka akan semakin rendah pula Self-Confidence (kepercayaan diri)nya.

\section{KESIMPULAN}

Berdasarkan hasil analisis dan pembahasan yang dilakukan pada penelitian ini, yaitu diperoleh kesimpulkan antar lain:

1. Ada hubungan yang searah atau positif antara self-confidence (kepercayaan diri) siswa dengan kemampuan komunikasi matematik dengan koefisien korelasinya yaitu 0,865. Semakin tinggi selfconfidence (kepercayaan diri) siswa akan semakin tinggi pula kemampuan komunikasi matematik yang dimiliki, Begitupun sebaliknya semakin rendah kemampuan komunikasi matematik siswa semakin rendah pula Self-Convidence (kepercayaan diri siswa)

2. Self-confidence (kepercayaan diri) siswa termasuk dalam kelompok yang rendah atau masih kurang, hal ini dilihat dari jawaban siswa/i yang positif yaitu sebesar $11,11 \%$ atau 4 orang dan $27,77 \%$ atau 10 orang pada jawaban siswa yang negatif. 
Kemamapuan komunikasi matematik siswa tergolong sedang yaitu sebesar 41,67\% atau 15 orang siswa dapat membaca soal dalam bentuk gambar, diagram, dan menghubungkan benda nyata, kedalam ide matematika, siswa dapat menjelaskan ide, dan menghubungkannya kedalam matematika melalui benda nyata, tulisan gambar, diagram, dan melalui simbol atau bahasa matematika siswa dapat menyatakan idenya kedalam peristiwa sehari-hari.

\section{DAFTAR PUSTAKA}

Afrilianto, M., \& Rosyana, T. (2016). Peningkatan Kemampuan Komunikasi Matematik Siswa SMP dengan Pendekatan Metaphorical Thinking. Prosiding Seminar Nasional Matematika Dan Pendidikan Matematika STKIP Siliwangi, 4.

Elida, N. (2012). Meningkatkan Kemampuan Komunikasi Matematik Siswa Sekolah Menengah Pertama melalui Pembelajaran Think-Talk-Write (TTW). Jurnal Ilmiah Program Studi Matematika STKIP Siliwangi Bandung, 1(2), 178-185.

Hendriana, H. (2013). Membangun Kepercayaan Diri Siswa Melalui Pembelajaran Matematika Humanis. Prosiding Seminar Nasional Matematika Dan Pendidikan Matematika STKIP Siliwangi Bandung, 1.

Hendriana, H., Rohaeti, E. E., \& Sumarmo, U. (2017). Hard Skills dan Soft Skills Matematik Siswa (I). Bandung: Refika Aditama.

Rahayuningdyah, E. (2016). Upaya Meningkatkan Kepercayaan Diri Melalui Layanan Konseling Kelompok Pada Siswa Kelas VIII D Di SMP Negeri 3 Ngrambe. JIPE, 1(2), $1-14$.

Rahmaningsih, N. D., \& Martani, W. (2014). Dinamika Konsep Diri pada Remaja Perempuan Pembaca Teenlit. Jurnal Psikologi, 41(2), 179-189.

Rahmi, S., Nadia, R., Hasibah, B., \& Hidayat, W. (2017). The Relation between Self-Efficacy toward Math with the Math Communication Competence. Infinity Journal, 6(2), 177-182.

Salam, R. (2014). Efektivitas Penggunaan Model Pembelajaran Kooperatif Tipe Think Pair Share (TPS) untuk Meningkatkan Kepercayaan Diri dan Komunikasi Matematis Siswa SMAN 9 Makassar. Jurnal Nalar Pendidikan, 2(2), 152-157.

Sidik, A., Ramlah, \& Utami, M. R. (2017). Hubungan Antara Self-Confidence dengan Kemampuan Komunikasi Matematis Siswa SMP. Prosiding Seminar Nasional Matematika Dan Pendidikan Matematika (SESIOMADIKA), 222-226.

Sritresna, T. (2017). Meningkatkan Kemampuan Komunikasi Matematis dan Self- Confidence Siswa melalui Model Pembelajaran Cycle 7E. Mosharafa, 6(3), 419-430.

Sumarmo, U., Mulyani, E., \& Hidayat, W. (2018). Mathematical Communication Ability and Self Confidence Experiment with Eleventh Grade Students Using Scientific Approach. JIML-Journal of Innovative Mathematics Learning, 1(1), 19-30.

Tresnawati, Hidayat, W., \& Rohaeti, E. E. (2017). Kemampuan Berpikir Kritis Matematis dan 
Kepercayaan Diri Siswa SMA. Pasundan Journal of Research in Mathemathics Learning and Education, 2(2), 116-122.

Zakiah, L., Saomi, A. S. N., Syara, R., Hidayat, W., \& Hendriana, H. (2018). THE EFFICIENCY OF USING EDUCATION VIDEOS ON THE LINEAR PROGRAM MATERIAL AS OBSERVED IN VOCATIONAL HIGH SCHOOL STUDENTS'MATHEMATICAL COMMUNICATION ABILITY.Journal Of Educational Experts (JEE), 1(1), 11-18. 